\title{
Papers
}

\section{Use of injections in healthcare settings worldwide, 2000: literature review and regional estimates}

\author{
Yvan J F Hutin, Anja M Hauri, Gregory L Armstrong
}

\begin{abstract}
Objective To describe injection practices worldwide in terms of frequency and safety.

Design Literature review. The global burden of disease project of the World Health Organization defined 14 regions on the basis of geography and mortality patterns. Data sources included published studies and unpublished WHO reports. Studies were reviewed by using a standardised decision making algorithm to generate region specific estimates. Setting Healthcare facilities, both formal and informal.

Data sources: General population and users of healthcare facilities.

Main outcome measure Annual number of injections per person and proportion of injections administered with syringes or needles, or both, reused in the absence of sterilisation.

Results The analysis excluded four regions (predominantly affluent, developed nations) where reuse of injection equipment in the absence of sterilisation was assumed to be negligible. In the 10 other regions, the annual ratio of injections per person ranged from 1.7 to 11.3 . Of these, the proportion administered with equipment reused in the absence of sterilisation ranged from $1.2 \%$ to $75.0 \%$. Reuse was highest in the South East Asia region "D" (seven countries, mostly located in South Asia), the eastern Mediterranean region "D" (nine countries, mostly located in the Middle East crescent), and the western Pacific region "B" (22 countries). No information regarding injection safety was available for Latin America.

Conclusions Overuse of injections and unsafe practices are still common in developing and transitional countries. An urgent need exists to use injections safely and appropriately, to prevent healthcare associated infections with HIV and other bloodborne pathogens.
\end{abstract}

\section{Introduction}

Poor injection practices have been reported worldwide. ${ }^{12}$ Many injections are unnecessary and unsafe. ${ }^{3}$ Of particular concern is the reuse of injection equipment in the absence of sterilisation (fig 1). The combination of injection overuse and unsafe practices results in a major route of transmission for hepatitis B virus $^{4}$ and hepatitis $\mathrm{C}$ virus. ${ }^{5}$ Other complications of unsafe injections include infection with HIV, ${ }^{6}$ abscesses, ${ }^{7}$ septicaemia, ${ }^{8}$ malaria, ${ }^{9}$ and viral haemorrhagic fevers. ${ }^{10} 11$

As part of the 2000 update of the World Health Organization's study of the global burden of disease, ${ }^{12}{ }^{13}$ we estimated the global burden of disease attributable to contaminated injections in healthcare setting. This paper summarises the input variables of the mathematical model in terms of the annual number of injections per person and the proportion of injections administered with syringes and needles that are reused in the absence of sterilisation.

\section{Methods \\ Definitions}

\section{Healthcare injection}

We defined a healthcare injection as a procedure that introduces a substance into the body through a piercing of the skin or a mucosal membrane for the purposes of curative or preventive health care, whether administered in a formal healthcare setting (for example, a clinic or hospital) or other settings (such as homes or pharmacies). Injections of illicit drugs were not considered in this study.

Reuse of injection equipment in the absence of sterilisation We defined reuse of injection equipment in the absence of sterilisation as the administration of an

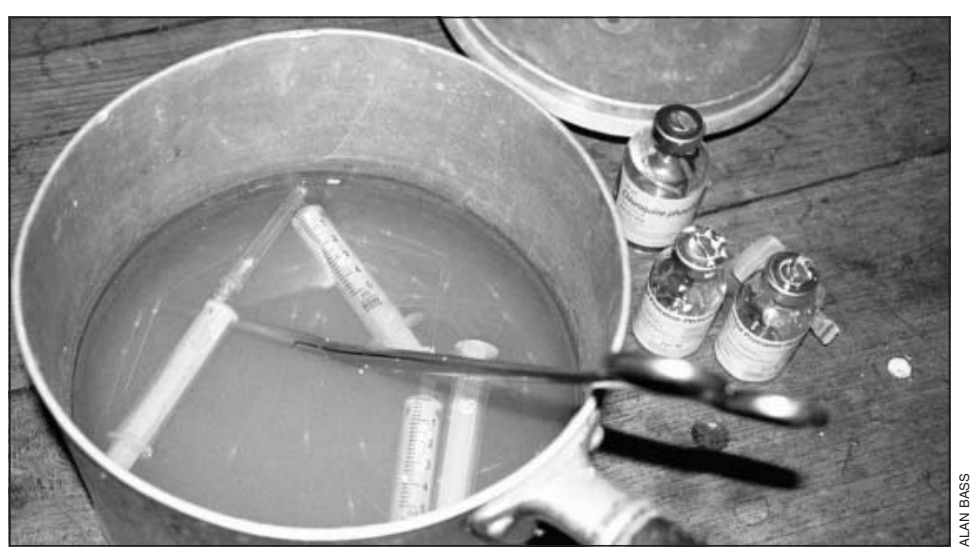

Fig 1 Injection equipment soaked in tepid water before reuse in the absence of sterilisation, Africa, 2000. Note the plastic syringes rinsed in the tepid water and the multidose medication vials
Department of Blood Safety and Clinical Technology, World Health Organization, CH-1211 Geneva, Switzerland.

Yvan J F Hutin medical officer Anja M Hauri medical officer

Division of Viral Hepatitis, National Center for Infectious Diseases, Centers for Disease Control and Prevention, 1600 Clifton Road, Atlanta, GA 30333 , USA

Gregory L Armstrong medical epidemiologist

Correspondence to Y J F Hutin hutiny@who.int

bmj.com 2003;327:1075

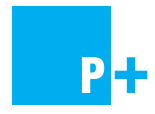

Additional references $w 1-w 21$ appear on bmj.com Avenue Appia, 20, 
injection to a recipient with a syringe or a needle that had been used previously on another person and that was reused in the absence of sterilisation. In this paper we will refer to reuse of injection equipment in the absence of sterilisation simply as "reuse of injection equipment."

\section{Sources of information used for the estimation of injection practices indicators}

Regions used

The regions from the 2000 study of the global burden of disease that were used in this analysis were based on the WHO regions. ${ }^{14}$ These $\mathrm{WHO}$ regions were then subdivided into subgroups (box) that were similar for selected vital statistics, including child and adult mortality. Subgroups were designated with a letter ("A" reflecting the lowest mortality and "E" reflecting the highest mortality). ${ }^{14}$

\section{Injection practices indicators}

We excluded four regions (European A, eastern Mediterranean B, American A, and Western Pacific A) that represented mostly industrialised countries as we considered the proportion of reuse negligible. To overcome the paucity of information available regarding injection practices in the published literature, we used exhaustive search strategies and unpublished reports. We searched published studies in Medline and the Index Medicus, using "injection" as a keyword. In addition we searched unpublished WHO reports, including evaluations of the expanded programme of immunisation (EPI) and other reports circulated since 1999 through the SIGNpost electronic mail newsletter. ${ }^{15}{ }^{16}$ We also reviewed relevant references quoted

\section{Countries included in the global burden of disease regions}

African region D includes: Algeria, Angola, Benin, Burkina Faso, Cameroon, Cape Verde, Chad, Comoros, Equatorial Guinea, Gabon, Gambia, Ghana, Guinea, Guinea-Bissau, Liberia, Madagascar, Mali, Mauritania, Mauritius, Niger, Nigeria, Sao Tome and Principe, Senegal, Seychelles, Sierra Leone, Togo.

African region E includes: Botswana, Burundi, Central African Republic, Congo, Côte d'Ivoire, Democratic Republic of the Congo, Eritrea, Ethiopia, Kenya, Lesotho, Malawi, Mozambique, Namibia, Rwanda, South Africa, Swaziland, Uganda, United Republic of Tanzania, Zambia, Zimbabwe. American region B includes: Antigua and Barbuda, Argentina, Bahamas, Barbados, Belize, Brazil, Chile, Colombia, Costa Rica, Dominica, Dominican Republic, El Salvador, Grenada, Guyana, Honduras, Jamaica, Mexico, Panama, Paraguay, Saint Kitts and Nevis, Saint Lucia, Saint Vincent and the Grenadines, Suriname, Trinidad and Tobago, Uruguay, Venezuela. American region D includes: Bolivia, Ecuador, Guatemala, Haiti, Nicaragua, Peru. Eastern Mediterranean region D includes: Afghanistan, Djibouti, Egypt, Iraq, Morocco, Pakistan, Somalia, Sudan, Yemen.

European region B includes: Albania, Armenia, Azerbaijan, Bosnia and Herzegovina, Bulgaria, Georgia, Kyrgyzstan, Poland, Romania, Slovakia, Tajikistan, Macedonia, Turkey, Turkmenistan, Uzbekistan, Yugoslavia. European region C includes: Belarus, Estonia, Hungary, Kazakhstan, Latvia, Lithuania, Republic of Moldova, Russian Federation, Ukraine.

South East Asia region B includes: Indonesia, Sri Lanka, Thailand. South East Asia region D includes: Bangladesh, Bhutan, North Korea, India, Maldives, Myanmar, Nepal.

Western Pacific region B includes: Cambodia, China, Cook Islands, Fiji, Kiribati, Laos, Malaysia, Marshall Islands, Federated States of Micronesia, Mongolia, Nauru, Niue, Palau, Papua New Guinea, Philippines, Republic of Korea, Samoa, Solomon Islands, Tonga, Tuvalu, Vanuatu, Vietnam. in identified articles. We used a standardised study abstraction instrument to review all studies, appraised them according to their quality, and entered them into an electronic database.

To estimate the annual number of injections per person for each region, age, and sex, we restricted our selection to, firstly, population based surveys conducted for the purpose of estimating the frequency of injections and, secondly, other population based data providing estimates of the frequency of injections. In each region, we averaged the estimates of all studies, corrected for the distribution of injections among male and female recipients and among age groups if one of the studies in the region provided that information. Finally, we corrected for additional immunisation injections among children under 5 if the data source did not take this factor into account.

To estimate the proportion of reuse for each region stratum, we restricted our selection to standardised observational studies of injection practices ${ }^{17}$ and studies of injection practices conducted by using nonstandardised methods. In the absence of data in some regions, we back calculated the proportion of reuse using a mass action equation ${ }^{18} 19$ and the relative risks of infection with bloodborne pathogens associated with receiving injections published in analytical epidemiological studies. In each region, we averaged the estimates of all studies. We excluded estimates based on non-standardised methods if assessments using the WHO standardised tool were available (the limitations of non-standardised assessments included nonrepresentative sampling, small sample sizes, and the absence of observations). We considered estimates based on back calculation only if higher quality information was not available (except in the eastern Mediterranean region, where the injection safety assessment focused mostly on the informal private sector).

\section{Uncertainty analysis}

We used standard error formulas to calculate the upper and lower estimates for the annual number of injections per person and the proportion of reuse. When the proportion of reuse was estimated on the basis of measures of association, the standard error was derived from the proportion and the sample size of the study. For regions for which good quality data were available on injection frequency (injection frequency surveys) or injection safety (standardised or nonstandardised injection safety surveys) we calculated the lower and upper estimates on the basis of a $95 \%$ confidence interval (2 standard errors). For regions for which only lower quality data were available we used an arbitrarily larger interval to account for added uncertainty (4 standard errors).

\section{Results}

Regional estimates of the annual number of injections per person

In eight regions surveys had been conducted with the objective of estimating injection frequency (table 1). ${ }^{20-23}$ w1-w4 In seven regions we obtained other population based information from control groups of case-control studies that examined the use of injection as a potential risk factor for various conditions. ${ }^{5}{ }^{\mathrm{w} 5 \mathrm{w} 14}$ The European region $\mathrm{C}$ had the highest injection fre- 
Table 1 Regional injection frequency estimates and data sources used, by region, 2000

\begin{tabular}{|c|c|c|c|c|c|c|c|c|c|c|}
\hline & \multicolumn{2}{|c|}{ African regions } & \multicolumn{2}{|c|}{ American regions } & \multirow{2}{*}{$\begin{array}{c}\text { Eastern } \\
\text { Mediterranean } \\
\text { region }\end{array}$} & \multicolumn{2}{|c|}{ European regions } & \multicolumn{2}{|c|}{ South East Asia regions } & \multirow{2}{*}{$\begin{array}{l}\text { Western } \\
\text { Pacific } \\
\text { region }\end{array}$} \\
\hline & D & $E$ & B & D & & B & C & B & D & \\
\hline $\begin{array}{l}\text { Annual No of } \\
\text { injections per } \\
\text { person* }\end{array}$ & 2.2 & 2.0 & 1.7 & 1.9 & 4.3 & 5.2 & 11.3 & 2.1 & 4.0 & 2.4 \\
\hline $\begin{array}{l}\text { Lower and upper } \\
\text { estimates* }\end{array}$ & $2.1-2.3$ & $2.0-2.0$ & $1.6--1.8$ & $1.2-2.7$ & $4.2-4.3$ & $4.3-6.1$ & $10.1-12.5$ & $2.1-2.2$ & $3.8-4.2$ & $2.1-2.7$ \\
\hline $\begin{array}{l}\text { Countries from } \\
\text { which injection } \\
\text { frequency surveys } \\
\text { were used }\end{array}$ & $\begin{array}{l}\text { Guinea } \\
\text { Bissauw }^{\text {w1 }}\end{array}$ & $\begin{array}{l}\text { Central African } \\
\text { Republic } \\
\text { Côte d'Ivoire } \\
\text { Tanzania } \\
\text { Zambia } \\
\text { Burundi'1 } \\
\text { Ugandaw2 }^{\text {w2 }}\end{array}$ & Brazil $^{w 1}$ & - & Egypt $^{22}$ & Romania $^{20}$ & Moldova $^{21}$ & $\begin{array}{l}\text { Thailand }{ }^{w 11} \text { w3 } \\
\text { Indonesiaw15 }\end{array}$ & India ${ }^{23}$ & - \\
\hline $\begin{array}{l}\text { Countries from } \\
\text { which other } \\
\text { population based } \\
\text { data were used }\end{array}$ & $\begin{array}{l}\text { Cameroonw5 }^{w 5} \\
\text { Nigeriaw6 }^{w 6}\end{array}$ & Tanzania $^{\text {w8 w9 }}$ & $\begin{array}{c}\text { Latino } \\
\text { communities in } \\
\text { the USA20 }\end{array}$ & Haitiw10 & Pakistan $^{5}$ & - & - & - & India ${ }^{\text {w7 }}$ & $\begin{array}{c}\text { China, } \\
\text { Taiwan"w1-w14 }\end{array}$ \\
\hline $\begin{array}{l}\text { Use of different } \\
\text { estimates for } \\
\text { male and female } \\
\text { recipients of } \\
\text { injections }\end{array}$ & No & Yes & No & No & No & Yes & Yes & No & No & No \\
\hline $\begin{array}{l}\text { Addition of } 0.5 \\
\text { injections per year } \\
\text { among children } \\
\text { aged } 1-4 \text { to } \\
\text { account for } \\
\text { immunisation }\end{array}$ & Yes & Yes & Yes & Yes & Yes & No† & Not & Not & Yes & Not \\
\hline
\end{tabular}

*Estimates are age adjusted, using age group specific population sizes to simplify data presentation. The total estimate is based on age and sex specific estimates. †Not applicable: age specific injection frequency estimate takes into account immunisation injections.

quency, followed by European region B (11.3 and 5.2 injections per person and per year, respectively, fig 2). The regions with the lowest annual number of injections per person were the American regions $\mathrm{B}$ and $\mathrm{D}$ (1.7 and 1.9 injections per person and per year, respectively). Overall, the annual number of injections per person was 3.4

Regional estimates of the proportion of reuse Eleven observational injection safety surveys had been conducted by using the standard WHO tool in three regions (WHO unpublished data, table 2). Four non-standardised observational injection safety surveys had been conducted in four regions. ${ }^{24} 25$ w15 w16 Two epidemiological studies were available to provide relative risks associated with receiving injections. ${ }^{4}{ }^{\text {w17 }}$ No

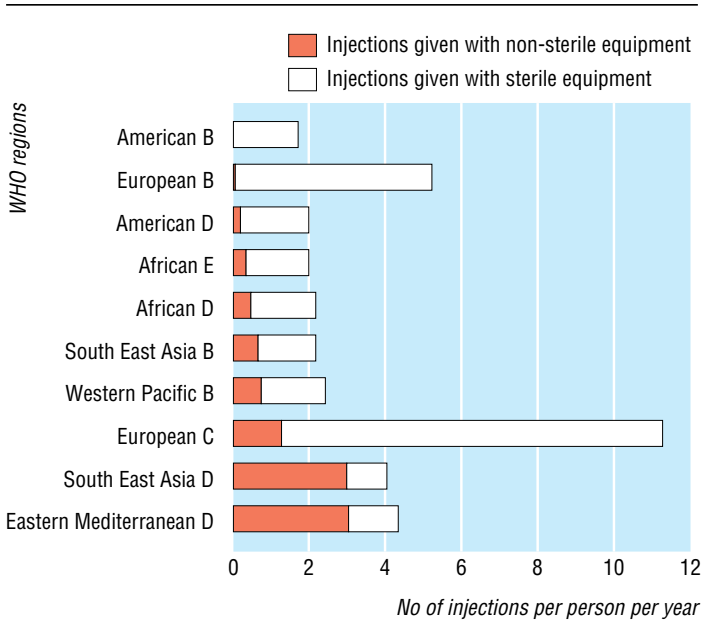

Fig 2 Number of injections per person and per year and proportion of these administered with injection equipment reused in the absence of sterilisation, by region, 2000 quantitative data were available for the two regions of Latin America despite qualitative reports of reuse. ${ }^{\text {w18-w2 } 21}$ Among regions for which quantified estimates were available, South East Asia region D was the region with the highest proportion of reuse $(75 \%)$, followed by eastern Mediterranean region D (70\%) and western Pacific region B (30.0\%, fig 2). The region with the lowest proportion of reuse was European region B (1.2\%).

\section{Discussion}

In the year 2000 the safe and appropriate use of injections remains elusive. ${ }^{20-27}$ Under the conservative assumption that the regions in Latin America for which no data were available would follow the pattern of reuse observed in eastern and central Europe, we estimated that 6.7 billion (39.3\% of all) were given with reused equipment each year. These figures constitute a call for action since effective and affordable interventions are available.

The high frequency of injections reported contrasts with the paucity of data that are available to describe them. In that respect, our study should be seen more as a first attempt to organise information in this field and underline the need for better quality data. Until recently, few tools for assessment or evaluation were available. The WHO programme on essential drugs proposed the proportion of prescriptions including at least one injection as a critical indicator of rational drug use. ${ }^{28-30}$ The demographic and health surveys (DHS) have included questionnaire items regarding injections received in some countries. ${ }^{31}$ The expanded programme on immunisation has conducted nonstandardised surveys into the safety of injections surveys for several years. Since 2000 these assessments have been conducted systematically and with a standardised tool. ${ }^{17}$ 
Our analysis indicates over16 billion injections each year in the 10 regions included in our study. The crude annual number of injections per person was the highest in the former socialist economies of the European region. Most injections in these countries are administered in public facilities, with a high number of injections per prescription. ${ }^{20}{ }^{21}$ Although providers commonly emphasise patients' demand as a major driver of injection overuse, surveys indicate that patients are open to alternatives to injections. ${ }^{20} 32$ Prescribers overestimate patients' preference for injections and have false preconceptions about their effectiveness. ${ }^{33}$ Prescribers' attitudes thus also contribute to overuse of injections. Use of injections was also high in the Middle East and South Asia. In these regions a high proportion of injections is administered by informal private providers. ${ }^{22}{ }^{24}{ }^{25}$ In such settings, providers' attitudes also drive injection overuse. ${ }^{54}$ Injections are often used on an ad hoc basis to administer mixtures of medications, in the desire to meet what is believed to be the demand of the user. ${ }^{24}{ }^{34}$

Our review indicates that injections are given in a way that may harm the recipient. Determinants of these unsafe injection practices include the lack of single use injecting devices, ${ }^{35}$ the lack of awareness of the risk of HIV infection associated with unsafe injections, ${ }^{23}{ }^{24}$ and the absence of sharps waste management. ${ }^{36}$ Interestingly, injection practices are safer in sub-Saharan African than in the Middle East and South Asia. The proportion of the population aware of the potential risk of HIV infection through unsafe injections was 24\% in Pakistan in 1998 (Steve Luby, Centers for Disease Control and Prevention, personal communication, 2000), $19 \%$ in India in $1999,{ }^{23}$ and $52 \%$ in Burkina Faso in 2001. ${ }^{37}$ The consequences of the HIV pandemic have been perceived more acutely in Africa than in Asia. A higher awareness regarding the risks of HIV infection associated with unsafe injec- tions in sub-Saharan Africa ${ }^{38}$ may therefore partly explain this difference observed in the proportion of reuse.

\section{Limitations}

This study has several limitations. Firstly, we did not estimate the frequency of other breaks in infection control practices that can also lead to infection. ${ }^{39}{ }^{40}$ Secondly, observer induced modifications to behaviours may have led to better practices in some surveys of facilities. Thirdly, we examined only the risks associated with unsafe injections among recipients of injections. A separate study was conducted to estimate the frequency of needlestick injuries among healthcare workers, ${ }^{41}$ but the adverse health consequences of poor management of sharps waste on communities have not been measured. Fourthly, publication bias could have affected our results if studies were initiated in response to perception that injection practices were poor in a particular location. Finally, the frequency distribution of the number of injections received tends to be skewed to the right because of a small proportion of the population receiving a very high number of injections (for example, diabetes patients). Some of the studies that we included may have had a sample size too small to include these individuals. Our injection frequency estimates may therefore be underestimated and not be usable directly to forecast injection equipment needs.

\section{Recommendations}

Policies for the safe and appropriate use of injections aim to eliminate unnecessary injections and to achieve safe practices. $^{42}$ Firstly, HIV programmes should communicate the risks associated with unsafe injections. Secondly, essential drugs programmes should ensure access to single use injection devices and build rational use of injections in the national drug policy. Thirdly, donors and lenders who supply injectable sub-

\begin{tabular}{|c|c|c|c|c|c|c|c|c|c|c|}
\hline & \multicolumn{2}{|c|}{ African regions } & \multicolumn{2}{|c|}{ American regions } & \multirow{2}{*}{$\begin{array}{c}\text { Eastern } \\
\text { Mediterranean } \\
\text { region }\end{array}$} & \multicolumn{2}{|c|}{ European regions } & \multicolumn{2}{|c|}{ South East Asia regions } & \multirow{2}{*}{$\begin{array}{c}\text { Western } \\
\text { Pacific } \\
\text { region } \\
\text { B }\end{array}$} \\
\hline & D & $\mathrm{E}$ & B & D & & B & C & B & D & \\
\hline $\begin{array}{l}\text { Proportion of reuse } \\
(\%)\end{array}$ & 19 & 17 & $\mathrm{~N} / \mathrm{A}^{*}$ & $N / A^{*}$ & 70 & 1.2 & 11 & 30 & 75 & 30 \\
\hline $\begin{array}{c}\text { Lower and upper } \\
\text { estimates (\%) }\end{array}$ & $15-23$ & $13-21$ & $\mathrm{~N} / \mathrm{A}^{*}$ & $N / A^{*}$ & $58-82$ & $0-4$ & 3-19 & $23-37$ & $60-88$ & $0-63$ \\
\hline Methods used & $\begin{array}{l}\text { Standard WHO } \\
\text { survey }\end{array}$ & $\begin{array}{c}\text { Standard WHO } \\
\text { survey }\end{array}$ & - & - & $\begin{array}{l}\text { Combination of } \\
\text { methods }\end{array}$ & $\begin{array}{l}\text { Standard WHO } \\
\text { survey }\end{array}$ & $\begin{array}{c}\text { Back } \\
\text { calculation }\end{array}$ & $\begin{array}{l}\text { Non-standard } \\
\text { surveys }\end{array}$ & $\begin{array}{l}\text { on-standard } \\
\text { surveys }\end{array}$ & $\begin{array}{l}\text { Non-standard } \\
\text { surveys }\end{array}$ \\
\hline $\begin{array}{l}\text { Countries from } \\
\text { which WHO } \\
\text { standardised } \\
\text { injection safety } \\
\text { surveys were } \\
\text { used }\end{array}$ & $\begin{array}{l}\text { Five countries } \\
\text { in the regiont‡ }\end{array}$ & $\begin{array}{l}\text { Five countries } \\
\text { in the regiontł }\end{array}$ & - & - & - & Kyrgyzstan $\ddagger$ & - & - & - & - \\
\hline $\begin{array}{l}\text { Countries from } \\
\text { which non } \\
\text { standardised } \\
\text { injection safety } \\
\text { surveys were } \\
\text { used } \\
\end{array}$ & - & - & - & - & Pakistan $^{24}$ & - & - & Indonesiaw15 & India ${ }^{25}$ & China $^{\text {w16 }}$ \\
\hline $\begin{array}{l}\text { Countries from } \\
\text { which back } \\
\text { calculated } \\
\text { injection safety } \\
\text { estimates were } \\
\text { used }\end{array}$ & - & - & - & - & Egypt ${ }^{w 17}$ & - & Moldova $^{4}$ & - & - & - \\
\hline
\end{tabular}

*Not available.

+Unpublished WHO reports. List of actual countries not available to the general public.

łJulia Fitzner, Department of Vaccine and Biologicals, WHO, personal communication, 2002. 


\section{What is already known on this topic}

Unsafe healthcare injections can transmit bloodborne pathogens

\section{What this study adds}

Overuse of injections is common in developing and transitional countries, reaching 3.4 injections per person per year

Reuse of injection equipment in the absence of sterilisation occurs in almost one in three injections in developing and transitional countries

stances should also fund adequate quantities of single use injection devices. Fourthly, health systems should manage sharps waste. Fifthly, indicators of injection practices should be monitored as technical quality indicators of the performance of health systems. Finally, the specific issue of informal private providers may require specific targeted interventions. A new WHO guide for assessment, and response ${ }^{43}$ proposes a list of indicators together with data collection instruments so that injection practices can be assessed and evaluated systematically.

We thank Steve Luby, Majid Ezzati, Anthony Rodgers, Annette Pruess for critical comments on the methodology and on the manuscript, and Julia Fitzner for providing the results of the injection safety assessments coordinated by WHO's Department of Vaccines and Biologicals.

Contributors: YJFH wrote the article and supervised the project. He has access to all the data, accepts full responsibility for the content, and is the guarantor of this work. AMH reviewed the literature, incorporated the data into the mathematical model, and participated in revisions of the manuscript. GLA conceptualised the mathematical model and participated in revisions of the manuscript.

Funding: WHO Department of Blood Safety and Clinical Technology. Donors and partners contributing to the unspecified extrabudgetary funds of the Department of Blood Safety and Clinical Technology include the governments of the Netherlands, United Kingdom, and Norway.

Competing interests: None declared.

1 Simonsen L, Kane A, Lloyd J, Zaffran M, Kane M. Unsafe injections in the developing world and transmission of blood-borne pathogens. Bull WHO 1999;77:789-800.

2 Drucker E, Alcabes PG, Marx PA. The injection century: massive unsterile injections and the emergence of human pathogens. Lancel 2001;358:1989-92.

3 Reeler AV. Injections: a fatal attraction? Soc Sci Med 1990;31:1119-25.

4 Hutin YJF, Harpaz R, Drobeniuc J, Melnic A, Ray C, Favorov M, et al Injections given in healthcare settings as a major source of acute hepatitis B in Moldova. Int J Epidemiol 1999;28:782-6.

5 Luby SP, Qamruddin K, Shah AA, Omair A, Pahsa O, Khan AJ, et al. The relationship between therapeutic injections and high prevalence of hepatitis C infection in Hafizabad, Pakistan. Epidemiol Infect 1997;119:349-56

Hersh BS, Popovici F, Jezek Z, Satten GA, Apetrei RC, Beldescu N, et al. Risk factors for HIV infection among abandoned Romanian children. AIDS 1993; 7:1617-24

7 Soeters R, Aus C. Hazards of injectable therapy. Trop Doct 1989;19:124-6

8 Archibald LK, Ramos M, Arduino MJ, Aguero SM, Deseda C, Banerjee S, et al. Enterobacter cloacae and Pseudomonas aeruginosa polymicrobial bloodstream infections traced to extrinsic contamination of a dextrose multidose vial. J Pediatr 1998;133:640-4.

9 Abulrahi HA, Bohlega EA, Fontaine RE, Al-Seghayer SM, Al-Ruweis AA Plasmodium falciparum malaria transmitted in hospital through heparin locks. Lancet 1997;349:23-5.

10 World Health Organization. Ebola haemorrhagic fever in Zaire, 1976. Bull WHO 1978;56:271-93.

11 Fisher-Hoch SP, Tomori O, Nasidi A, Perez-Oronoz GI, Fakile Y, Hutwagner L, et al. Review of cases of nosocomial Lassa fever in Nigeria: the high price of poor medical practice. $B M J 1995 ; 311: 857-9$.
12 Murray CL, Lopez AD. On the comparable quantification of health risks: lessons from the global burden of disease study. Epidemiology 1999;10:594-605.

13 Murray CJL, Lopez AD. The global burden of disease: a comprehensive assessment of mortality and disability from diseases, injury and risk factors in 1990 and projected to 2020. Geneva: World Health Organization, 1996.

14 World Health Organization. World Health Report 2000. Health systems: improving performance. Geneva: WHO, 2000:204-5.

15 Hutin YJF, Chen RT. Injection safety: a global challenge. Bull WHO 1999;77:787-8.

16 Bass A. SIGNpost: the safe injection global network internet forum listserve. Bull WHO 2000;18:277.

17 World Health Organization. Tool for the assessment of injection safety. Geneva: WHO, 2001. (WHO/V\&B/01.30.)

18 Aylward B, Kane M, McNair-Scott R, Hu DJ. Model-based estimates of the isk of human immunodeficiency virus and hepatitis B virus transmission through unsafe injections. Int J Epidemiol 1995;24:446-52.

19 Kane A, Lloyd J, Zaffran M, Simonsen L, Kane M. Transmission of hepatitis $\mathrm{B}$, hepatitis $\mathrm{C}$ and human immunodeficiency viruses through unsafe injections in the developing world: model-based regional estimates. Bull WHO 1999,77:801-7.

20 Centers for Disease Control and Prevention. Frequency of vaccinerelated and therapeutic injection-Romania 1998. MMWR Morb Mortal Wkly Rep 1999;48:271-4.

21 World Health Organization. High frequency of therapeutic injections, Republic of Moldova. Wkly Epidemiol Rec 1999;11:84-6.

22 Talaat M, El Oun S, Kandeel A, Abu-Rabei W, Bodenschatz C, Lohiniva $\mathrm{AL}$, et al. Overview of injection practices in two governorates in Egypt. Trop Med Int Health 2003;8:234-41.

23 Undergraduate study team, Anand K, Pandav CS, Kapoor SK. Injection use in a village in North India. Natl Med J India 2001;14:143-4.

24 Khan AJ, Luby SP, Fikree FF, Karim A, Obaid S, Dellawala S, et al. Unsafe injections and the transmission of hepatitis $\mathrm{B}$ and $\mathrm{C}$ in a periurban community in Pakistan. Bull WHO 2000;78:956-63.

25 Lakshman M, Nichter M. Contamination of medicine injection paraphernalia used by registered medical practitioners in south India: an ethnographic study. Soc Sci Med 2000;51:11-28.

26 Role of syringes in the transmission of jaundice. A memorandum by medical officers of the ministry of health. Lancet 1945;(28 July):116-9.

27 Wyatt HV. The popularity of injections in the third world: origins and consequences for poliomyelitis. Soc Sci Med 1984; 19:911-5.

28 World Health Organization. Indicators for monitoring national drug policies. WHO action programme on essential drugs. Geneva: WHO, 1994. (WHO/DAP/94.12.)

29 Quick JD, Rankin JR, Laing RO, O'Connor RW, Hogerzeil HV, Dukes MNG, et al, eds. Managing drug supply. 1st ed. West Hartford: Kumarian Press, 1997:430-9.

30 Prawitasari Hadiyono JE, Suryawati S, Danu SS, Sunartono, Santoso B. Interactional group discussion: results of a controlled trial using a behavioural intervention to reduce the use of injections in public health faciliioural intervention to reduce the
ties. Soc Sci Med 1996; $42: 1177-83$

31 Demographic and Health Surveys. Measure DHS+ (2000). Survey methods available at www.measuredhs.com (accessed 29 Sep 2003).

32 Vong S, Perz J, Hutin Y, Drobeniuc J, Bell BP, 1998 International Field Epidemiology Course Participants. Determinants of high frequency of therapeutic injections, Chisinau, Republic of Moldova, 1998. Abstract presented at the 51st Epidemic Intelligence Service Conference, Centers for Disease Control, Atlanta, GA, USA, April 2002.

33 Stoica A, Hutin YJF, Paun M, Mast EE, Margolis HS. Attitudes of physicians regarding the use of therapeutic injections, Arges district, Romania Abstract presented at the annual meeting of the Society for Healthcare EpidemiPresen

34 Altaf A, Aoboatwalla M, Luby S, Hutin Y, Fatmi Z, Ajmal A, et al. In depth interviews of healthcare providers, patients and carers of infants to identify determinants of therapeutic injections in Sindh, Pakistan. Abstract \# MoPeD3666 presented at the XIV International AIDS Conference 2002, Barcelona, 7-12 July 2002.

35 Dicko M, Oni AQ, Ganivet S, Kone S, Pierre L, Jacquet B. Safety of immunization injections in Africa: not simply a problem of logistics. Bull WHO 2000;78:163-9.

36 Hofmann CA. The WHO injection safety assessment tool: first results. In: Safe injection global network (SIGN). Annual meeting report, 30-31 August 2001. (WHO/BCT/DCT/01.04.)

37 Logez S. Accessibility to injection equipment: impact on injection safety. WHO mission report. Clermont Ferrand: Pharmaciens Sans Frontières Comité International, June 2001

38 Birungi H. Injections and self-help: risk and trust in Ugandan healthcare. Soc Sci Med 1998;47:1455-62

39 Alter MJ, Ahtone J, Maynard JE. Hepatitis B virus transmission associated with a multiple-dose vial in a hemodialysis unit. Ann Intern Med 1983;99:330-3.

40 Centers for Disease Control. Injection practices among nurses-Valcea, Romania, 1998. MMWR Morb Mortal Wkly Rep 2001;50:59-61.

41 Sharps injuries among healthcare workers. In: World Health Organization. World Health Report 2002: Reducing risks, promoting healthy life. Geneva: WHO, 2002:74. (Box 4.4.)

42 World Health Organization. Aide mémoire for a national strategy for the safe and appropriate use of injections. Geneva: Department of Blood Safety and Clinical Technology, 2000.

43 World Health Organization. Injection practices: rapid assessment and response guide. Geneva: WHO, 2001. (WHO/BCT 02.11.)

(Accepted 6 September) 